\title{
Public service providers and users in the information society
}

- An explorative analysis

Associate Professor Bernt Krohn Solvang

E-mail: Bernt.k.Solvang@hia.no

Phone no. +4737253147

Agder University College

Faculty of Economics and Social Sciences

Department of Industrial Management

Grooseveien 36

4890 Grimstad

PhD candidate Charlotte Kiland

E-mail: Charlotte.Kiland@hia.no

Phone no. +47 38141689

Agder University College

Faculty of Economics and Social Sciences

Department of Political Science and Management

Serviceboks 422

4604 Kristiansand 


\section{Public service providers and users in the information society}

\section{- An explorative analysis}

\section{Introduction}

$\mathrm{T}$ he issue to be discussed in this article is to what extent does ICT create new challenges for the relationship between public service providers and users? It is important to recognize the concept of social capital because the concept is vital to the understanding of access to the information society and efficient functioning of government in its service to citizens. In this way we see social capital as a mediating "institution" between public authorities and the citizens (users).

With this paper we hope to stimulate a public discussion and increase the awareness of the main challenges for public services and their users in the information society. By pointing out some main characteristics of the development of the welfare state up to present day, we discuss how information and communication technology (ICT) has influenced both past challenges and will influence new challenges in the information society. ICT is technology based on electronic impulses and can be understood as series of O's and 1's. Examples are computers, digital cameras, handheld devices such as mobile phones, the Internet etc.

Today, the working conditions for people delivering public services and the users' (citizens') access to public services meet new challenges, and this affects the significance of the social capital concept. By focusing on the relationship between ICT and social capital, the overall argument in this paper is that ICT may enhance social capital, both from horizontal and hierarchical points of view. This implies that the public sector is aware of and allows for the new challenges the sector and its users face in the information society.

ICT may reduce transaction costs and thereby increase the possibility of establishing relationships at a lower cost and at a wider range. At micro level this may encourage face-to-face contact and thus increase the foundation and development of social capital. At macro level government and public services must meet demands such as developing and increasing transparency, access to information and resources to users through well-designed e-governance initiatives and programmes. The paper will also bring into focus and discuss in which way the use of ICT may prepare for more communitarian ${ }^{1}$ values and thereby strengthen the foundation and building of social capital. By considering ICT as a critical element in enhancing social capital and developing the infrastructure in a society, an increasing awareness of how this development affects the role of the public service providers and the users is important in all social planning.

\section{The concept of social capital}

Social capital is a complex concept. The definition and emphasis of this concept will vary according to different disciplines. An often quoted social capital definition is the one by Coleman (1990: 302), who formulates the concept as follows:

\footnotetext{
${ }^{1}$ The concept refers to political and social philosophy that emphasizes the importance of community in the functioning of political life, in the analysis and evaluation of political institutions, and in understanding human identity and well-being (Britannica Online).
} 
"Social capital is defined by its function. It is not a single entity, but a variety of different entities having two characteristics in common: They all consists of some aspect of a social structure, and they facilitate certain actions of individuals who are within the structure"

Coleman's focus is on how obligations, expectations, norms and sanctions influence both individual and collective action/ behaviour. Lyngstad (2003) points out "social capital" and "the civil society" as two main concepts of communitarism. Coleman's definition can be linked to what Etzioni (1995) defines as communitarian values, emphasizing a common set of values and norms (as mentioned above).

The occurrence of social capital can be attached to the citizens' formal and informal network in civil society. A central element in the definition of the concept of social capital is trust or the occurrence of mutual trust between individuals in society (Putnam 1993; 2000). 'Social capital' is therefore different from other categories of capital (e.g. economical or human). It is not a recourse controlled by individuals, but a characteristic of the relations linking individuals together in a society and hence constitutes an important condition for social integration, democratic stability and efficiency and economical efficiency (Coleman 1990; Putnam 1993). Another version of the definition of social capital is the one used by Putnam (1993:167):

"...features of social organization, such as trust, norms, and networks, which can improve the efficiency of society by facilitating coordinated actions".

Seligman (1997:39-40) does not define the establishment of trust as a product of social (formal and informal) networks existing in civil society. Instead, Seligman defines trust as more individually altered. Trust is seen as a kind of condition for the individuals' opportunity of action and social integration. His argument is that several characteristics of social relations in modern society, e.g. more roles and more complex and differentiated role-sets, greater number of reference group members, weaken our possibilities to predict or control what kind of behaviour we can expect from the individuals in society.

"The greater indeterminacy and the greater negotiability of role expectations lead to the greater possibility for the development of trust as a form of social relations...Broadly speaking, the more confidence in a system of role expectations cannot be taken for granted (because of the systematically "mandated" possibility of dissonance in role fulfilment and expectations), the more difficult it becomes to establish reciprocity which can only be met by the establishment of trust" (ibid).

Various types of social capital have been discussed in several articles. E.g. Torsvik (2000) distinguishes between civic social capital and governmental social capital. It is difficult to find an adequate typology and definition of social capital. Still, a concept ought to be fruitful and one property linked to fruitful concepts is its contents of intentions and denotations (Zaltman, Pinson \& Anglemar 1973). The intention of a concept deals with what sorts of properties the concept has. The properties linked to the concept of social capital are trust and potential for social integration. The denotations of the social capital concept are the classes of objects and happenings linked to the intentions or the properties of the concept. In our definition the denotations are individuals, organized groups (organizations) and institutions. Based on this argument we propose the following definition of social capital: institutions', organized groups' or individuals' degree of trust and the potential for integration and cooperation, and a strengthening of the social structure in both horizontal and vertical relations. Thus, considered as a feature, trust and the potential for integration and cooperation constitute social capital. In our definition horizontal relations refer to more homogenous individuals, groups or institutions, whereas vertical relations refer to individuals, groups or institutions in a hierarchical structure or relationship. The idea of social capital is attached to formal and informal relationships to 
have a mediating function of information between the citizens and the public authorities. A strengthening of social capital can improve the relations between the two "partners".

\section{Users and their access to public services}

The democratic ideal of equality assumes that citizens have equal opportunities for participation (Dahl 1984). However, inquiries indicate that the ideal of equal opportunity does not exist in reality. The access to political resources which can be used for political participation is systematically unequally distributed (Martinussen 1973). Political participation requires resources such as time, money, positions, prestige and education to overcome the costs of active participation (Martinussen 1973). Even though the votes count in elections, resources are crucial (Rokkan 1987). Often the demands for increased participation from the users of public services have coincided with the demands for greater social equality among specific groups of users (Bleiklie et al 1994).

The relationship between citizens and central and local government administration is structured by different rules. In order to gain access to public services, citizens must accept certain conditions. The potential users of the public services must pass several barriers before the service can be provided. Some of these barriers are a threshold for political rights and registration, a threshold for competence, and an efficiency threshold with queue and counter (Martinussen 1973; Schaffer and Huang 1975; Bleiklie et al 1994). The accessibility structure in the administrative distribution system consists of three elements:

- Threshold

- Queue

- Counter

(Bleiklie et al.1994:329).

The threshold is a set of access rules in which the users are limited to certain categories. Before these access rules are applied the users must overcome physical and perhaps even psychological obstructions (Martinussen 1973). The queue is governed by a set of preference rules, and the counter is a set of assigned rules that describes the interaction between the civil servants and the users (ibid.). In order to pass the threshold the users must acknowledge their needs and have the knowledge and the information about how the service can remedy the needs, overcome the physical and social distances to the services and describe their case in hand in a way that justifies their enquiry. To pass the queue the users must avoid a lower priority, especially if priority has not already been given. In order to succeed, users must manage the interaction with the civil servants (Bleiklie et al 1994: 335-363).

It is reasonable to assume that there are different types of problems regarding thresholds among socially deprived groups. There might be discrepancy between given information about performance and users' ability to interpret the information (Hoven 1988). Potential users may have negative expectations of the performance because they do not expect to get any help, and because they perceive the interaction and the procedure of application as difficult and unpleasant (Hoven 1981; Bleiklie 1990; Bleiklie et al 1994). There might be a discrepancy between the different needs of the potential users and the public regulations that define the criteria for the right/ legitimacy of the performance/ service (Bleiklie et al 1994:339).

Problems regarding the threshold might also be connected to the strategies the civil servants use to protect themselves against a vast influx of users, who are regarded as unpleasant or less qualified for the service (ibid.). As a principle there is no room for queue and problems regarding priority. Nevertheless, the civil servants' procedures may differ from the formal rules. The services/ performances might be limited and result in pressure to let the civil servants deviate from the formal rules of priority. Some services are partly controlled by the market 
and thus outside the civil servants' control (Hoven 1981). This indicates that the principle of equality is under pressure from other considerations and values.

The counter is made up by the interactions between civil servants and users. As a principle there is no room for any interaction problems because of distinct rules both parts are expected to follow and be aware of (Bleiklie et al 1994:342). Still, problems concerning interaction and prioritizing may appear because of indistinct rules. In addition to this, interaction is also regulated by the activity and the initiatives of both the civil servants and the users (ibid.).

\section{The basic properties of ICT}

What are the basic properties of information and communication technology? Four fundamental aspects of the digital technology have been identified (Murray 1997; Hanson 2000). These are: Procedural, participatory, spatial and encyclopaedic.

Digital technology as procedural is related to the fact that computers are programmable machines that can store, retrieve, and process data in a procedural manner. Well programmed computers can shape beautiful illustrations of intelligence and focus on details. The second aspect is digital technology as participatory. The technology invites the user to participate. The user may give instructions and the software systems find information and respond. The responds are tailor-made to fit in with the instructions made by the user. A third aspect is digital technology as spatial. The technology makes it possible to create virtual rooms. The rooms may produce familiarity and comfort for the users. The last fundamental aspect is digital technology as encyclopaedic. Digital information may be stored cheaply. Huge amounts of information can be stored and made available in a fraction of a second. (Hanson 2000:3946). These properties afforded by digital technology lay a new foundation for the production of public services.

Digital technology creates new working conditions for all types of work in public services, especially in providing information about the service that is offered. We may talk of a new service logic in which links between the parameters in service production have been untied as a consequence of digital technology. Instead of producing the main contents of the service in front of the user, the main contents may, as a consequence of digital technology, be produced and stored in advance and then be provided to the user when needed. Increased ICT maturity (to the extent that an organization uses ICT) reduces the transaction costs for both the organisation and the customer. The reduced transaction costs influence the relationship between the supplier and the customer (Williamson 1975; Amit \& Zott 2001).

In the private sector the technology shift has laid the foundations for what has been described as new business logic (Normann and Ramirez 1994). The working conditions for business have been changed as a result of a reduction in transaction costs in production, in partnering and in relations with customers (Normann 2001). In the public sector IT maturity will appear at various levels of Information System Portals (Holmes 2001). A higher level of portals forms the basis for e-governance through "implementing cost-effective models for citizens, industry, federal employees and other arms of government" (Whitson 2001: 79). A higher level of portals implies increased horizontal organisational forms in a public sector where roles are changing organizations and co-ordination systems (Holmes 2001; Bannister 2001). Within the public sector the effects are linked to cost reduction, reduction in waiting time and increased relationship quality (Gassan et al. 2001). Digital technology will influence the bureaucratic form of the organisation. And, the technology will make it easier to create virtual organisational forms in which public servants will occupy new roles as integrators (Normann 2001; Ahuja \& Carley 1999; Galbraith 2002). The full potential of ICT from the citizen's perspective can only be achieved by horizontally integrated government services across different functional walls (Lagne \& Lee 2001:132). 


\section{ICT - a reform wave in the new millennium}

Today, much of the rhetoric seems to be dominated by the idea that we live in an information society. Several times in the last 10 to 20 years we have heard about the vision of a social revolution driven by a development in information technology (IT) through large-scale initiatives.

During the 1990's, governments in many countries published strategic plans for ICTdevelopment with national action plans, e.g. in Norway such a plan was implemented in 1987 (Buland 1996). Different reform experiments have been carried out, connected to e-democracy, e- governance etc. From 1987 to 1990 an annual budget 1 billion NOK was allocated for the implementation of these reform experiments in the Norwegian public sector (Buland 1996).

Emphasis on information and communication technology (ICT) has once more become an overriding political issue. It is now seen as a critical element of a supportive infrastructure. There is pressure on people working in the public services to use this technology in the organisation and the evaluation of the services. The citizens' access to the Internet is emphasised. This access has increased both in homes, schools and working places. Today, half of all Norwegians (2.2 mill people) have access to the Internet, and one million of these people go on line every day.

It is interesting to reflect on how the use of ICT can prepare the way for a civil society characterized by "...networks, norms and trust - that enable participants to act together more effectively to pursue shared objectives" (Putnam 1993:664-665). In other words, to what extent can the use of ICT prepare and increase the formation of social capital in the civil society? ICT has the potential for development at both micro and macro levels by offering unique opportunities to access instant information, increase knowledge, sharing and community building, reach new markets and thus generate social capital.

Calabrese and Borchert (1996) argue that information and communication technology creates a networking infrastructure, which encourages the formation of social capital. At the same time, ICT can have an anonymizing, deindividuating effect which relaxes social norms and even leads to disintegration of social capital (Loeh and Conger 1996). Given "digitally divided" populations, there is a risk that ICT will exclude rural and regional areas, poor people and entire societies. ICT requires online participation through expensive computers, telephone and broadband access, and literacy skills. Physical access to computers does not guarantee access to the information society. This risk of exclusion challenges the government to focus on narrowing the social disparities and the ICT divide. These challenges will also have an impact on public service providers and users. 


\section{The expansion of the welfare state}

The interaction between public service providers and users can be described as a development through different phases (Baldersheim 1993:155; Ståhlberg 1996:54). From the development and the expansion of the Nordic welfare state during the period from 1945 to the end of the 70's, the first period can be characterized by a centralization of the welfare state with strong confidence in the public sector. The development of the principles of universality and equality prevailed in the public sector. The allocation criteria were based on citizens' needs. The welfare state policy was centrally administered and initiated and can be characterized as a "top-down" process (Ståhlberg 1996; Baldersheim 1993). The welfare state was built on a communitarian social view, underlined by a common responsibility as citizens to take care of and maintain society.

In the mid 1970's the political system in Norway was described as 'segmented'. This segmentation was perhaps a result of different divides in the Norwegian society. The segmentation did not follow institutional borders, but took place in different fields and arenas where sector interests dominated and separated the governmental organisation and the public interests into vertical pillars with weakened coordination mechanisms (Østerud et al 1997).

In the 1980's the confidence in the public sector was still strong, but local government initiatives and influence became even stronger as they were used as agents for implementing several of the national welfare programmes. This development gave source to the expression "the welfare commune" or the local welfare state (Grønlie1991). This period has been described as a "bottom-up" process and a period characterized by a decentralized welfare state. This kind of decentralization to the local government level is a typical Norwegian ideology, as other countries to a greater extent decentralized through privatization to voluntary and private actors.

At the end of the 1980's and at the beginning of the 1990's confidence in the public service production was questioned (Ståhlberg 1996). Problems connected to resource stagnation and quality demands in the wake of the expansion of new local government tasks and areas of responsibility, resulted in different organizational reforms, aimed at solving political and administrative problems in local government (Bäck 2000:12). During this period a new phase began in the organisation of public service production. Decentralization was still emphasised. Among other factors, opening up for competition between different service providers, both public and private, resulted in a phase which has later been characterised as a fragmentation of service production. There was an extension of the concept of 'citizenship rights'. Society became more individualized with respect to relations between the authorities and each individual citizen (Østerud et al 2001). In this new liberal and market oriented phase there was an increased focus on the freedom of individual choice in which demands for efficiency were the primary objective. The citizens were to a greater extent seen as consumers or users and the public service production and supply were regulated by demands. Based on the development of the welfare state it may be reasonable to ask whether this development really has contributed to a strengthening of communitarian values.

Today, some scientists would describe the last phase, especially in the Scandinavian countries and at the local level, as a decentralisation to the voluntary and private sector. After years of market supremacy, several reforms now focus on participatory democracy, networking relations, interaction between public and private actors and different channels for influence (e.g. e-democracy), both as citizens, clients, users and members (Sørensen 1999; Taylor 2003; Montin 2002; Øgård 2001).

1 In this paper we focus primarily on the development of the Scandinavian welfare state. 


\section{A strengthening of communitarian values?}

Over the last ten years development has been characterized by a change from 'government' to 'governance' or a change from a representative democracy to partnerships, networks and network democracy etc (Øgård 2001; Olsson and Montin 1999; Elander 1999). To a greater extent, the arena of politics has been transferred from the representative bodies to different public and private organisations (Montin 2002).

Some would argue that this development can be interpreted as a stagnation of the new liberal and market-oriented influence on local government reforms (Lyngstad 2003:137). In addition to the individual's moral responsibility for the formulation of the society, aspects such as the community and collective gain strength in the local self-government (ibid). As an alternative to the public policies and the private market, several scientists refer to communitarism (Etzioni 1995; Tam 1998; Ståhlberg 1998). In contrast to new liberalism, which underlines the principle of mutual obligation where the individual is assumed to take rational choices based on self-interest, communitarism sees the individuals as part of a collective sphere where actions and attitudes are conceived over time in interaction with others. The principle of mutual responsibility is emphasized and assumes that trust, norms and values have a regulating function on the members of the civil society (Tam 1998).

\section{Information portals as access points in public service production}

An information portal can be seen as the citizens' gateway to the system of public service production. Five levels of portals have been identified, and each level represents a specific degree of ICT maturity (Holms 2001:23-24).

The first portal level provides information or service more easily. It hides the complexity of the public administration. Several governments have come to level one and are aiming to resch higher levels. The second level offers online transactions such as vehicle registration, business licensing, tax filing, and bill payment. The third level lets people jump from one service to another without having to authenticate themselves again. This requires coordination between different agencies and common authentication and security solutions. The fourth level of portal extracts data needed for transaction from all available public sources. This requires collaboration between organizations, as well as data warehousing and middleware technology so that different databases can exchange data. The fifth and highest level of portals adds a new dimension to the interaction and allows people to interact with the authorities on their own terms. At this level citizens will get aggregated and customized information and services in subject areas matching the citizens' situation. This requires customized organization of public service production. 


\section{The relationship between ICT and social capital}

Lin (2001:237) maintains that the rise of the Internet has resulted in a revolutionary growth of social capital. In a welfare state based upon ICT systems, social capital is regarded as an important factor in gaining access to the information society (Warschauer 2003:317). Another argument is that ICT can extend and enhance social capital. Williamson (1975, 1991) claims that the building of social capital is influenced by ICT. The technology creates lower transaction costs and makes it easier to build social relations between various actors and institutions in the information society.

Warschauer (2003:317) refers to studies providing evidence of the importance of social capital in gaining computer access. ${ }^{2}$ He calls for efforts to make use of ICT to promote social capital at three overlapping levels. The first level is the micro level, which refers to the relations with friends, relatives, and colleagues etc. that provide opportunities for community development, emotional support, information and companionship. The second level is the macro level, which corresponds to the effectiveness of government institutions, transparent and trustworthy relationships that exist between the government and service users. The third level, the meso level, corresponds to the voluntary associations and political organizations. This level allows people opportunities to form alliances and collectively defend their interest (ibid).

\footnotetext{
2 For a detailed insight of the studies: a) Regional Technology Alliance (2001): Mapping a future for digital connections: a study of the digital divide in San Diego County. September 2001.http://www.sdrta.org/sdrta. aboutsdrta/RTA Report 0201.pdf

b) Stanley, L.D. (2003): Beyond access: psychosocial barriers to computer literacy, In The information society, Vol 19, Nov-Dec
} 


\section{New challenges for the government, public service providers and users in the information society}

\section{Barriers}

Due to the emphasis on ICT in the public sector, some barriers have become even more evident than in the past. Today, barriers may exist in the form of inequality, lack of financial support, leadership, professional facilitation, technological development and support and vision. The use of ICT is heavily emphasized as a superior political issue through central and local government commitments to ICT projects and programmes that require major resources. Still, public service providers and users often experience that limited budgets result in a lower priority on ICT. The extent of ICT usage and access to ICT may vary between sectors and levels of government, and because of inequality linked to geography (rural vs. urban areas) and economy. To prevent and reduce poverty and marginalization of socially deprived users, these barriers can be marginalized with well designed application of ICT.

\section{E-governance initiatives}

Taken into account how ICT influence the new challenges of public service production and the users in the information society, public sector should increase the awareness of how social capital and ICT investments must be integrally related and interdependent (Alter 2002).

An important issue is to develop and design e-governance initiatives and programmes that can help increase governmental legitimacy and the potential for trust among service providers and users. Hence, access to public information and resources is fundamental. Warschauer (2003:325) points out transparency and citizen feedback as two important factors. Developing transparent information and documentation systems could improve the quality of public services and also increase efficiency and productivity.

Both the Organization for Economic Cooperation and Development (OECD) and the World Bank have acknowledged the importance of social capital for economic and social development:

"Trust [social capital] has a role in facilitating productivity... when embodied in the organisational culture of firms... and may lead to larger and more effective production units... as well ac enhanced cooperation within firms. Social capital can facilitate regional systems of innovation... helps people to find jobs (OECD 2001: 57-58)".

A higher level of portals forms the basis for e-governance and involves implementing costeffective models for citizens, industry, federal employees and other arms of government (Whitson 2001). Some models assume dramatically reduced waiting time and reduction costs with $20-45 \%$ at a higher level of ICT portals (Gassan et al 2001:65).

Other e-governance initiatives should include programmes for technology adaptation to different sectors and services. Well-designed ICT infrastructure through interactive services, which allow for marginalized groups, can reduce the distance between users and public service providers. This might increase the access to government resources and possibilities for user feedback. Online services prepare both for government's and public services' distribution of information and documentation to users, and provide the users with an instrument for more rapid and flexible feedback (Warschauer 2003). This is important in all social planning and paves the way for participation which is a fundamental aspect of democracy. 


\section{Implementing higher level of portals}

Integration of the various parts of public service production is a massive undertaking. The roles of the employees will change, and changed roles often bring about resistance against changed working conditions. In the fight against resistance based on fear and uncertainty, a participation process is the key to success. There are also juridical problems linked to implementation at a higher level of portals, which is responsible for the answer to the user (Johansen 1998).

\section{Safeguarding personal information from misuse}

At higher government portal levels various data needs to be sorted in order to be able to serve the citizens in an efficient way (Shiffman et al 1999). Another challenge is when communication becomes intrusive and threatens privacy protection (Baldersheim 2004).

\section{New organizational forms}

Virtual services can be produced in cooperation with private actors. This could mean a new role for the public agency in question, the role as a service integrator. The integrator role is one of several roles an actor may play in a virtual network (Galbraith 2002). The integrator coordinates decisions and activities by the actors who participate in the network, takes initiatives and responsibilities, and formulates goals and strategy for the whole service production (Galbraith 2002; Solvang 2004). The advantages of virtual organizing are linked to the fact that the public integrator has the power of action without mass in organizational recourses. Increased potential for value production has been seen as a main motive for virtual service production (Das \& Teng 2000). The virtual organization makes it easier to coordinate the work and to standardize the production (Malone et.al. 1987, Bakos \& Nault 1997, Solvang 2004).

Another impact of ICT on new organizational forms is more lateral patterns of communications through a levelling of hierarchy. There will probably be a downsizing of government organizations and this will lead to a new problem: what will become of unemployed government workers. However, new organizational forms might make it easier to organize cross-border learning through arenas and networks across borders of sectors and institutions (Baldersheim 2004).

\section{New roles}

As the public services are supposed to evaluate and inform the users about quality, access and services delivered through ICT, the citizens or the users have a greater choice. But, this also assumes that the users have the resources and the knowledge to be able to make rational choices. The users have to depend on the service providers' information about the services delivered. Active users who are able to search for information are probably better off than passive users who lack the resources to search for this kind of information. The easier access to information and the more informed users are, the better is the possibility for mutual trust between the provider and the users. The less informed users are, the more dependent they are on the service provider. This makes the impatient consumer the king. But citizens with benchmark information will probably be drivers of more intensive cross-border learning (Baldersheim 2004).

Both the role of the public service provider and the role of the citizen are being influenced by increased ICT maturity. As the citizens become more professional in their demands, public service providers are driven towards increased service orientation (Solvang 2004).

Still, Willard (2001) argues that most of the participants in online development networks are from elite institutions because not all development professionals, who could participate, are in 
positions to do so. This can partly be related to issues of skills, motivation and existing social capital. This could lead to a social and digital divide among workers in the public services and their working conditions and thus increase a more random service production for the users.

\section{Centralization of public service production to citizens}

The possibilities of centralizing selected information from all parts of the public services constitute a tremendous democratic problem in modern democracies. But there are no automatic effects of higher IT portal level on the degree of centralization of state power in a modern democracy (Kneebone 1992; Beland 2004; McKay 2000). The forces to promote centralization or decentralization would seem to be otherwise determined than society's level of ICT use.

\section{ICT and the values of the principles of universality and equity}

The universality principle was challenged in old society through unequal distribution of resources among the citizens. All service based on active citizens results in under-consumption of the service by those with poor resources. Sociological researches on social stratification have been summed up in the Matthew effect: "For those who have, to those shall be given and they shall have plenty, but for those who do not have, they shall have nothing and from them shall be taken what they have".

The properties of ICT reduce the transaction costs linked to public service access (Williamson 1975,1991 ), and with that the problem of the Matthew effect could diminish in the information society. But since the digital losers (Frønes 2002) are of the same quality as the losers in the Matthew effect, the Matthew effect is not completely removed.

The equity principle is challenged by digital technology's ability to provide tailor-made solutions. A service suitable for one citizen may not be suitable for another citizen. The citizens need services that cover their needs. The principle of equity does not imply that each citizen must have exactly the same service, but the right to have a service suitable to individual needs.

\section{ICT and the problems of access and segmentation}

The problem of access consists of access costs for the citizens and the fact that resources "to pay" the costs are unevenly distributed. These costs are linked to qualities in the government system with barriers and differentiation of service production (Huang 1975; Rokkan 1987; Bleiklie et al.1994).

Digital technology reduces access costs and hence also reduces the problem of access to public service production. But the access problem is not eliminated since the digital losers lack the resources to use the computer for their own purpose.

Even though segmentation implies strong social networks in which different groups of society are engaged, it might be difficult to coordinate and develop common ideas and actions. The segmented organization of public services might increase tension between different service providers and make comprehensive services difficult to achieve. The problem with public service segmentation is more easily solved in the information society since transactions costs are dramatically lowered, and the use of ICT makes it easier to communicate and organize cooperation and cross-boarder learning between the different service providers. 


\section{How does ICT influence the problem of individualization and the foundation of social capital?}

Harriss (2000) argues that a "dark side" of the social capital is that strong associations can be anti-social and detrimental to the needs and interests of society as a whole. This might indicate a paradox, in which building social capital increases individualization. Other researchers have found that social capital is an aid to adaptive efficiency, to creativity, learning and knowledgesharing and encourages cooperative behaviour (Burt 1992; Nahapiet and Ghoshal 1998).

Based on the conclusion of the last evaluation of democracy, the political and governmental systems and the civil society in Norway (Maktutredningen 1998-2003), a fragmentation of the state has taken place (Østerud et al 2001). The fragmentation of the system described has also stated some effects for public service production and how these effects increase the individualization of the services, and thereby challenge the communitarian ideas. Citizens seem to emphasize productivity and efficiency to a larger extent than equal assumptions and equality in the public services provided (Øgård 2001). This development implies weakened citizenship and decreased emphasis on communitarian values. In this respect, the foundation for social capital, according to Coleman's definition, appears to be complicated.

According to Seligman's (1997) definition of social capital, the fragmentation and individualization of the society make it more difficult to predict or control what kind of behaviour citizens can expect from each other and thereby complicate the foundation for trust and development of social capital. Harriss (2000) argues that an individual's social capital is another person's exclusion. In the public sector, where workers deal with a high level of social capital these working conditions can be associated with conflicts. Still, by reducing the costs of transactions, the effects of increased ICT usage are multiple. Evidence shows that companies are forming networks and clusters because of heavy IT investments. Motives of face- to face contact, generation of trust and cohesion and increased competitiveness encourage companies to locate in networks and clusters (Gulati et al 2000:203; Britton et al. 2004). The increased value of relations in business (Sawhney \& Zabin 2002) motivates companies to social interactions with each other and hence increases possibilities to enrich the employees' social capital. Modern work ethics stress cooperation and teamwork, and these aspects strengthen the ground for building and enriching the social capital of employees as well (Sennett 2001).

When transaction costs are reduced as a result of the increased use of ICT, the possibility to establish relationships at a lower cost and at a wider range might increase the motivation for face-to-face contacts. Thus, ICT can increase the building of social capital by strengthening social connections. Social relations probably became stronger and improve the foundation and building of social capital. Even though ICT might extend people's social capital, one can assume that ICT also results in diminished social contact. Less face-to-face interaction might cause social isolation. In relations between citizens and the government social capital could function as a mediating "institution" and strengthen the contacts between the government and the citizens.

\section{Concluding remarks}

How is ICT, social capital and the relationship between them of any relevance for public servants and users?

The development from the expansion of the welfare state into the information society has challenged public servants and users in new ways. Demands for easier access, improved and increased productivity, efficiency, quality and transparency have to some extent challenged roles and role expectations. This implies an increased individualization of the users assuming 
that they are capable of and have the recourses to gain adequate information and access to public services. An assumption for proper handling of these challenges in the public sector is a well-designed ICT infrastructure. E-governance initiatives and programmes can help increase legitimacy and the potential for trust among public servants and users. Hence, the importance of social capital for economic and social development and planning is a paradox. In one way, it could be argued that social capital is an assumption for user access to public services in the information society. From another point of view it can be argued that social capital is a result of increased degree of trust and the potential for integration and cooperation between public servants and the users through ICT.

However, strengthening of social capital as a function of increased ICT use will strengthen the functions of social capital as a mediating "institution" between government and citizens and hence contribute to improved relationships between the public authorities and clients thereby.

\section{Literature}

Ahuja, M.K. and Carley, K.M. (1999): Network Structure in Virtual Organizations, Organizations Science, Vol 10 No.6 Nov - Dec. pp 741-757.

Alter, T. (2002): The Role of Social Capital in Information Technology Development. National Community Resources and Economic Development Conference 2002. Orlando, FL: Penn State

Amit, R. and Zott, C.(2001): Value Creation in E- Business, Strategic Management Journal Vol 22 pp.493-520.

Bakos, J.Y., and Nault, B.R. (1997): Ownership and Investment i n Electronic Networks, Information Systems Research Vol. 8 No. 4.

Baldersheim, H. (1993): Kommunal organisering: Motar sel, men ressurser avgjer? I Lægreid, $\mathrm{P}$ og J.P.Olsen (red.): Organisering av offentlig sektor. Perspektiver - reformer erfaringer - utfordringer. Oslo: Tano

Baldersheim, H. (2004): Twenty Years of Local Government Reforms - European Models and Experiences. Forskerkurs 25.-28. nov 2004. Oslo: Universitetet i Oslo

Bannister, F. (2001): Dismantling the silos: extracting new value from IT investments in public administration, Information Systems Journal Vol 11 (2001) pp 65-84.

Bäck, H. (2000): Kommunpolitiker i den stora nyordningens tid . Malmö: Liber

Beland, D. (2004): Fighting 'big government':Frames, federalism, and social policy reform in the United States, Canadian Journal of Sociology - Cahiers Canadiens de Socilogie 29 (2) 2004.pp. 241-264

Bleiklie, I. (.. 1990 ):): Service Regimes. A Comparative Organizational Study of ClientOfficial Relations and Political Steering in Two Service Agencies. Rapport nr. 7. Institutt for administrasjon og organisasjonsvitenskap. Universitetet i Bergen.

Bleikelie, I., Jacobsen, K.D. og J. Thorsvik (1994): Forvaltingen og den enkelte. I Christensen,T og M. Egeberg (red.):Forvaltningskunnskap. 2 utg. Oslo: Tano 
Britton, N.J., Halfpenny, P., Devine, F. and R. Mellor (2004): The future of regional cities in the information age: The impact of information technology on Manchester's financial and business services sector. The Journal of British Sociological Association 38 (4) pp. 795-814.

Buland, T. (1996): Den store planen. Norges satsing på informasjonsteknologi i 1987 - 1990. STS-rapport nr. 27. Trondheim: Senter for teknologi og samfunn, NTNU

Burt, R. S. (1992): Structural Holes: the Social Structure of Competition. Cambridge: Harvard University Press

Calabrese, A. and M. Borchert (1996): Prospects for electronic democracy in the United States: Rethinking communications and social policy. Media, Culture and Society 18 : 249:268

Coleman, J.S. (1990): Foundations of Social Theory. Harvard: Harvard University Press

Das, T.K. and B-S. Teng (2000): A Resource- Based Theory of Strategic Alliances. Vol. 26, No 1 , pp 31-61.

Elander, I. (1999): Partnerskap och demokrati. Omaka par i nätverkspolitikens tid? I Amnå, E. (red): Globalisering. Demokratiutredningen. Forskarvolym IX SOU 1999:83

Etzioni, A. (1995): The Spirit of Community. Fontana

Frønes, I.(2001): Digitale skiller. Bergen: Fagbokforlaget.

Galbraith J.R. (2002): Designing organizations. UK: John Wiley \& sons

Gassan, A.-K.i, Boer de, K., Mourshed, M. and N. P. Rea (2001): Putting citizen on-line, not in line. The McKinsey Quarterly 1997 No. 2. (2001) pp 65-73.

Grønlie, T. (1991): Velferdskommunen. I Nagel, A.-H. (red.): Velferdskommunen. Kommunens rolle under utviklingen av velferdsstaten. Bergen: Alma Mater

Gulati, R., Nohira, N. and A. Zaheer (2000): Strategic networks . In Strategic Management Journal 21, pp.205-215.

Hanson, W. (2000): Principles of Internet Marketing. South-Western College Publishing.

Harriss, J. (2002): Depoliticizing Development: The World Bank and Social Capital. London: Anthem Press

Holmes, D. (2001): E-government, E-business Strategies for Government. Nicholas Brealey Publishing.

Hoven, F.H. (1981): Byråkratierfaringer og klientatferd. Publikasjon nr 10.

Forskningsprogrammet: Forvaltningen og svakstilte brukere. Bergen/ Kristiansand: Institutt for offentlig administrasjon Agder Distriktshøgskole.

Hoven, F.H. (1988): Informasjonskløftene og mulighetene for å ta ut rettigheter, I Omdahl, H (red): Informasjonskløftene og demokratiet. Oslo: Universitetsforlaget 
Johansen M.W. (1998): Elektronisk saksbehandling - noen juridiske problemstillinger ved elektronisk dokumentasjonshåndtering. Statskonsult. Rapport no. 13

Kneebone RD. (1992): Centralization and the size of Government in Canada. Applied Economics 24 (12) Pp. 1293-1300

Layne K.and Lee J. (2001): Developing fully functional E-government: A four stage model Government Information Quarterly, Vol 18 pp 122-136.

Lin, N. (2001): Social capital: a theory of social structure and action. Cambridge, Mass.: Cambridge University Press.

Loeh, K.D. and S. Conger (1996): Evaluating ethical decisions and computer use. Communications of the ACM 39 (3): 48-60

Lyngstad, R. (2003): Makt og avmakt i kommunepolitikken. Rammer, aktørar og ideologi i det lokale folkestyre. Bergen: Fagbokforlaget

Malone T.W. ,Yates J. and Benjamin R.I (1987): Electronic Markets and Electronic Hierarchies. Communication of the ACM.

Martinussen, W. (1993): Velferdsfellesskap. Medvirkning og solidaritet I nærmiljø, yrkesliv og politikk.

Trondheim: Allforsk AVH

McKay D. (2000): Policy legimacy and institutional design: Comparative lessons for the European Union. Journal of Common Market studies 38 (1) pp 25-44.

Montin, S. (2002): Moderna kommuner. Lund: Liber

Murray J. H. (1997): Hamlet on the Holoedeck: The Future of Narrative in Cyberspace. New York: Free Press

Nahapiet, J. and S. Ghoshal (1998): Social capital, intellectual capital and the organizational advantage, Academy of Management Review, 23 (2): 242-266

Normann R. (2001): Reframing Business. When the Map Changes the Landscape. UK: John Wiley \& sons

Norman, R and Ramirez, R (1994): Den nya affärslogiken. Liber-Hermods AB, Malmø

Olsson, J. og S. Montin (red.)(1999): Demokrati som experiment - försöksverksamhet och förnyelse i svenska kommuner. Ørebro: Ørebro universitet, Novemus. Nevemus rapportserie 1999:1

Organisation for Economic Cooperation and Development 2001. The Well-being of Nations: The Role of Human and Social Capital.Paris: OECD. http://www.oecd.org/ dataoecd/48/22/1870573.pdf

Peled, A. (2001): Centralization or diffusion? Two tales of online government, Administration \& Society 32 (6) pp 686-709.

Putnam, R. (1993): Making Democracy work. Civic Tradition in Modern Italy. Princeton: Princeton University Press. 
Putnam, R. (2000): Bowling alone. New York: Simen \& Schuster.

Rhodes, R.A.W.(1997): Understanding Governance. Policy networks, Governance, Reflexivity and Accountability. Buckingham: Open University Press

Rokkan, S. (1987): Stat, nasjon, klasse. Essays I politisk sosiologi. Oslo: Universitetsforlaget

Sawhney M. and Zabin J. (2002): Managing and Measuring Relations Equity in the Network Economy, Journal of the Academy of Marketing Science. Vol. 30, No.4, pp. 313-332.

Schaffer, B.B. and W.-H. Huang (1975): Distribution and the Theory of Access, In Development and Change, Vol 6: 13 - 36

Seligman, A.B. (1997): The Problem of Trust. Princeton: Princeton University Press

Sennett, R. (2001): Det fleksible mennesket. Bergen: Fagbokforlaget

Shiffman R. N, Brandt C.A., Liaw Y. and G.J. Corb (1999): A design model for computerbased guideline implementation based on information management services, Journal of the American Medical Informatics Association 6 (2) pp. 99-103 March - April

Solvang B.K.(2004): Effekter av informasjonsteknologi og valgfrihet på sentrale relasjoner i kommunal og privat tjenesteproduksjon. Arbeidsnotat nr.1.Agder University College, School of Management.

Ståhlberg, K. (1996): Herre I eget hus. 12 debattinnlägg om nordiska kommuner i förandring. Bergen: LOS - senteret. LOS - senter rapport 9605

Ståhlberg, K. (1998): Serviceförbindelser i kommunernas utvecklingspolitik, Kommunal ekonomi och politik 2:7-19

Sørensen, R. J., Borge, L.E., Hagen T.P (1999): Effektivitet i offentlig tjenesteyting. Fagbokforlaget.

Torsvik, G: (2000): Social capital and economic development. A plea for the mechanisms, in Rationality and Society 12 (4), pp. 451-476

Tam, H. (1998): Communitarianism. A New Agenda for Politics and Citizenship. MacMillan Press Ltd.

Taylor, M (2003): Public Policy in the Community. Palgrave MacMillan

Warschauer, M. (2003): Social capital and access. Univ Access Inf Soc 2, pp 315-330. Published online. Springer-Verlag.

Whitson, T.I, and L. Davis (2001): Best practices in electronic government: Comprehensive electronic information dissemination for science and technology, Government Information Quarterly, Vol 18 No 2

Williamson, O.E. (1975): Markets and Hierarchies. Analysis and Anti-Trust Implications. New York: Free Press (1975). 
Williamson O.E. (1991): Markets - The Logic of Economic Organization.

In Williamson, O.E. and S.G. Winter (eds): The Nature of the Firm. New York: Oxford Press, Inc.

Zaltman, G., Pinson, C.R.A. and R. Angleman (1973): Meta Theory and Consumer Research. New York: Holt, Rishardt and Winston

Øgård, M. (2000): New Public Management- markedet som redningsplanke. I Baldersheim, H. and L.E. Rose (red): Det kommunale laboratorium pp 32-34. Bergen: Fagbokforlaget.

Østerud, Ø., K. Goldmann og M.N. Pedersen (red.)(1997): Statsvitenskapelig leksikon. Oslo: Universitetsforlaget

Østerud, Ø. og B.S. Tranøy (red) (2001): Den fragmenterte staten. Reformer, makt og styring. Oslo: Universitetsforlaget 